\title{
POLLEN USE EFFICIENCY OF SUNFLOWER (Helianthus annuus L.) LINES cms 234 A AND RHA 6D-1
}

\author{
Sumathi, P., Nirmalakumari, A. ${ }^{*}$ and Muralidharan, V.
}

Center for Plant Breeding and Genetics, Tamil Nadu Agricultural University, Coimbatore 641 003, Tamil Nadu, India

Received: May 24, 2004 Accepted: November 22, 2005

\author{
SUMMARY
}

\begin{abstract}
A field experiment was conducted at Agricultural Research Station, Bhavanisagar, Tamil Nadu Agricultural University, Coimbatore, India during rabi (Sep-Oct) seasons of 2000 and 2001 to study the pollen use efficiency of sunflower lines cms $234 \mathrm{~A}$ and RHA 6D-1. The experiments consisted of four treatments, $100 \%$ pollen $\left(\mathrm{T}_{0}\right), 75 \%$ pollen plus $25 \%$ borax as filler material $\left(\mathrm{T}_{1}\right)$, $50 \%$ pollen plus $50 \%$ borax as filler material $\left(\mathrm{T}_{2}\right)$ and $50 \%$ pollen and $50 \%$ flour of finger millet (Eleusine coracana $\mathrm{L}$.) $\left(\mathrm{T}_{3}\right)$. The results showed that the treatments were significantly differed from each other. All the traits studied recorded superior performance only at $100 \%$ pollen availability; the seed yield was very much increased only with an assured availability of sufficient pollen for fertilization. The mean comparison of the treatments for all the characters was $\mathrm{T}_{0}>\mathrm{T}_{1}>\mathrm{T}_{2}>\mathrm{T}_{3}$. Though the seed yield was reduced to some extent while supplementing pollen with filler material, it was concluded that $75 \%$ pollen with $25 \%$ borax filler material may be used instead of $100 \%$ pollen, without affecting the economic yield much in the case of pollen scarcity /pollen insufficiency/ in locations where "pollen theft" is common. Borax can be used as supplement at the time of pollination. The use of flour of finger millet as the filler material in the case of pollen insufficiency during pollination does not have any effect on the seed yield and yield attributing characters. In that case the yield was affected only below $50 \%$ of pollen availability.
\end{abstract}

Key words: borax, filler material, finger millet flour, pollen use efficiency, sunflower

\section{INTRODUCTION}

Sunflower is a global oilseed crop of economic importance, which ranks third next to soybean and groundnut as a source of edible oil in the world. In India, sunflower was introduced in early seventies and holds as a potential oilseed crop. In

* Corresponding author, e-mail: sumivetri@yahoo.com 
allogamous crops like sunflower, pollen source and maternal influence assumes greater importance in determining seed yield as well as oil yield (Shankar Goud, 2000). The sporophytic type of self-incompatibility mechanism in sunflower has been reported by Habura (1957). This mechanism makes the ovule parent to accept foreign pollen in preference to its own pollen thus encouraging cross-pollination.

Though the crop has gained important place among farmers, the productivity of sunflower in India is much lower than the world's average. The seed production yield in sunflower is largely dependent on the proper pollination. Poor seed setting in sunflower is often considered to be a major reason for low yield. Some of the reasons for poor seed setting are self-incompatibility, absence of pollen vectors, insufficient nutrition and competition among developing seed themselves (Sindagi, 1979). In majority of the cases the pollination is very much inadequate or not properly followed, the pollen theft by honey bees in the early morning before pollination leading to non-availability of pollen to stigma resulting in poor seed set. Andrei (1998) reported that different amounts of pollen was released by the restorer lines in different seasons. Under this condition to avoid and/or manage the non-availability of pollen in sufficient quantity, pollen theft and economic use of pollen that is available in limited quantities and to increase the seed parent rows by reducing the pollen parent rows the study was carried out using the filler materials.

\section{MATERIAL AND METHODS}

The experiment was set up during rabi (September-October) seasons of 2000 and 2001 at an experimental farm of Agricultural Research Station, Bhavanisagar, Tamil Nadu Agricultural University, Coimbatore, India. The experiment was laid out in randomized complete block design with four replications. The parents of the sunflower hybrid KBSH-1, cms 234 A and RHA 6D-1, were raised in 3:1 ratio with a plot size of $5 \times 2.4 \mathrm{~m}$. To attain synchronization of flowering, female parent ( $\mathrm{cms}$ 234A) was sown 5 days earlier than the male parent (RHA 6D-1). The parent seeds were dibbled at a spacing of $60 \times 30 \mathrm{~cm}$. The four treatments consisted of control, $100 \%$ pollen $\left(\mathrm{T}_{0}\right), 75 \%$ pollen plus $25 \%$ borax as filler material $\left(\mathrm{T}_{1}\right), 50 \%$ pollen plus $50 \%$ borax as filler material $\left(\mathrm{T}_{2}\right)$ and $50 \%$ pollen with $50 \%$ finger millet (Eleusine corocana $\mathrm{L}$.) flour $\left(\mathrm{T}_{3}\right)$.

Hand pollination was carried out from the first ray floret opening for each treatment and continued up to 8 days. The pollination was done on alternate days. Pollen and filler materials were mixed on weight basis. During pollination care was taken to minimize the damage to the stigma by using soft muslin cloth to rub the pollen on heads. Each plant was covered with brown paper cover to assure the treatment effects. Ten plants were selected at random in female parent (cms $234 \mathrm{~A}$ ) for recording the observations on nine quantitative traits, days to $50 \%$ flowering, days to maturity, head diameter $(\mathrm{cm})$, seed weight per head $(\mathrm{g})$, yield of raw seed (kg/plot), yield of processed seed (kg/plot), seed husk ratio and five quality charac- 
ters, seed moisture at harvest $(\%)$, seedling length $(\mathrm{cm})$, germination percentage, seed vigor index and oil content (\%). The data were statistically analyzed using statistical methods suggested by Panse and Sukhatme (1967).

\section{RESULTS AND DISCUSSION}

\section{Effect of borax on seed number}

Statistical analysis showed significant differences among all the treatments for head diameter and seed number per head. Seed filling percentage showed no significant effect between treatments $\mathrm{T}_{2}$ and $\mathrm{T}_{3}$ (Table 1 ) in both seasons.

Table 1: Effect of filler materials in cms 234A sunflower

\begin{tabular}{|c|c|c|c|c|c|c|c|c|c|}
\hline \multirow{2}{*}{ Treatment } & \multicolumn{2}{|c|}{$\begin{array}{l}\text { Head diameter } \\
\text { (cm) }\end{array}$} & \multirow[t]{2}{*}{$\begin{array}{l}\text { Mean } \\
(\mathrm{cm})\end{array}$} & \multicolumn{2}{|c|}{$\begin{array}{l}\text { Seed filling } \\
\text { percentage }\end{array}$} & \multirow[t]{2}{*}{ Mean } & \multicolumn{2}{|c|}{$\begin{array}{l}\text { Seed number } \\
\text { per head }\end{array}$} & \multirow{2}{*}{ Mean } \\
\hline & 2000 & 2001 & & 2000 & 2001 & & 2000 & 2001 & \\
\hline$\overline{T_{0}}$ & 14.28 & 15.12 & 14.70 & 89.55 & 90.35 & 89.95 & 386.05 & 390.75 & 388.40 \\
\hline $\mathrm{T}_{1}$ & 12.93 & 13.20 & 13.07 & 87.35 & 88.38 & 87.87 & 333.95 & 330.88 & 332.40 \\
\hline $\mathrm{T}_{2}$ & 11.65 & 12.56 & 12.11 & 85.18 & 86.23 & 85.71 & 260.90 & 266.40 & 263.70 \\
\hline $\mathrm{T}_{3}$ & 10.50 & 11.22 & 10.86 & 84.30 & 85.36 & 84.83 & 214.70 & 212.03 & 213.40 \\
\hline SEd & 0.264 & 0.341 & & 0.717 & 0.752 & & 2.011 & 3.97 & \\
\hline CD 5\% & 0.596 & 0.771 & & 1.623 & 0.701 & & 4.55 & 8.99 & \\
\hline
\end{tabular}

Pollination with $100 \%$ pollen recorded highest seed number per head due to higher seed filling percentage and head diameter (Figures 1 and 2) followed by $75 \%$ pollen and $25 \%$ of borax. The availability of pollen grains for pollination was entirely fulfilled when $100 \%$ pollen used and hence the fertilization might be maximum resulting in high seed filling percentage in turn it reflected in the high seed number per head.

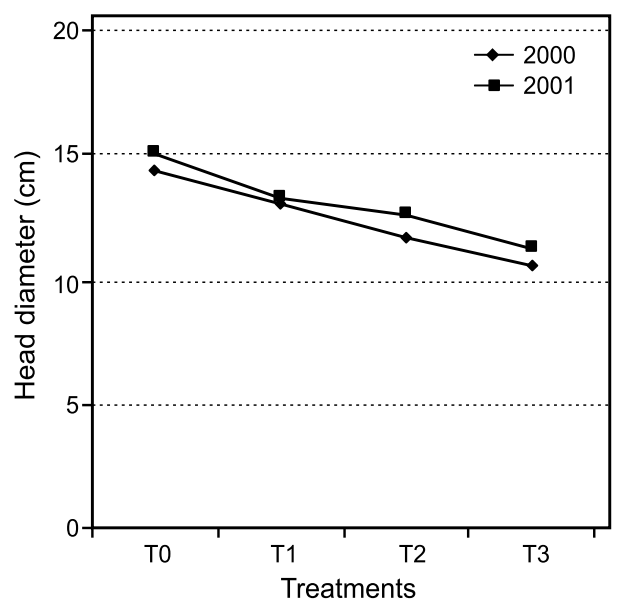

Figure 1: Effect of filler materials on mean of head diameter in sunflower

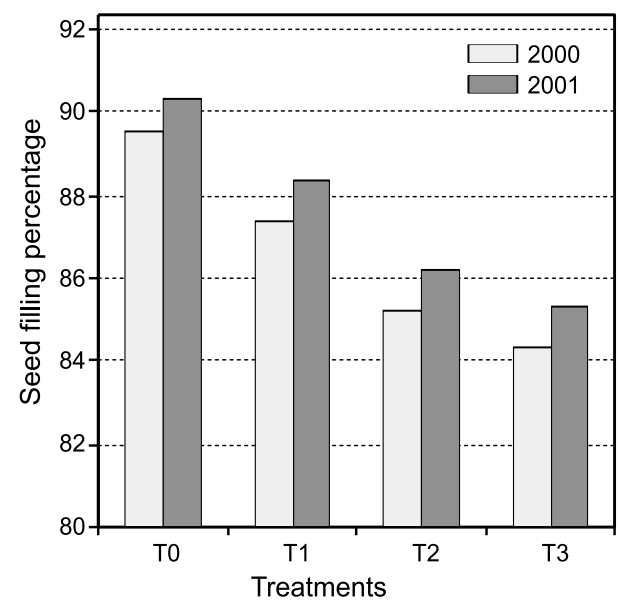

Figure 2: Effect of pollen and borax on mean of seed filling percentage in sunflower 
It is evidenced from the results that when the pollen percentage declined to 75 and $50 \%$ the seed number was also declined, (Figure 3), since the availability of the pollen is insufficient to pollinate all the stigmas. The mean comparison of the treatments was $\mathrm{T}_{0}>\mathrm{T}_{1}>\mathrm{T}_{2}>\mathrm{T}_{3}$. Seventy-five percent pollen with $25 \%$ of borax gave $86 \%$ seed number as on control. Borax is known to improve the pollen viability and fertilization and thereby improving the number of filled seeds. Narkhede and Patil (1989) reported that borax application alleviated the nutrient stress and increased the seed filling percentage.

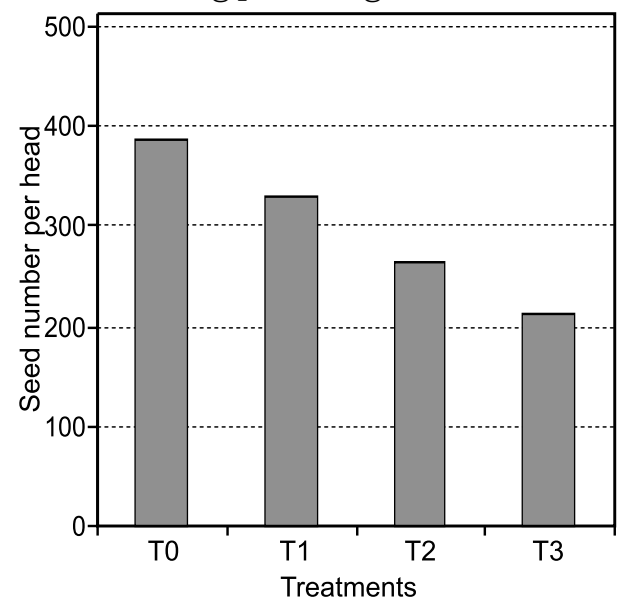

Figure 3: Relationship between pollen and filler materials on overall mean of seed number per head in sunflower

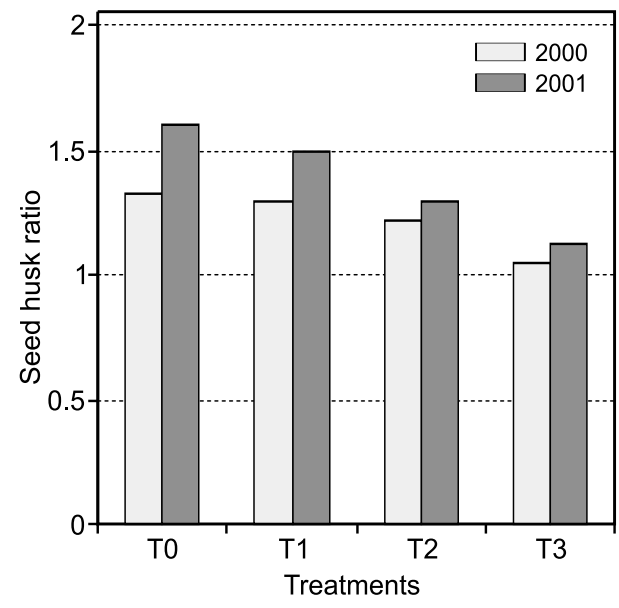

Figure 4: Effect of pollen and filler materials on mean of seed husk ratio in sunflower

Table 2: Effect of pollen on seed husk ratio, yield and oil content in cms 234A sunflower

\begin{tabular}{|c|c|c|c|c|c|c|c|c|c|}
\hline \multirow{2}{*}{ Treatment } & \multicolumn{2}{|c|}{$\begin{array}{l}\text { Seed husk } \\
\text { ratio }\end{array}$} & \multirow{2}{*}{ Mean } & \multicolumn{2}{|c|}{$\begin{array}{l}\text { Single plant } \\
\text { yield }(\mathrm{g})\end{array}$} & \multirow{2}{*}{ Mean } & \multicolumn{2}{|c|}{$\begin{array}{l}\text { Oil yield } \\
\text { (g) }\end{array}$} & \multirow{2}{*}{ Mean } \\
\hline & 2000 & 2001 & & 2000 & 2001 & & 2000 & 2001 & \\
\hline$\overline{T_{0}}$ & 1.33 & 1.60 & 1.47 & 14.23 & 15.45 & 14.84 & 5.67 & 6.26 & 5.97 \\
\hline $\mathrm{T}_{1}$ & 1.29 & 1.50 & 1.40 & 12.65 & 13.33 & 12.99 & 4.93 & 5.29 & 5.11 \\
\hline $\mathrm{T}_{2}$ & 1.22 & 1.29 & 1.26 & 10.84 & 10.23 & 10.54 & 4.18 & 4.00 & 4.09 \\
\hline $\mathrm{T}_{3}$ & 1.05 & 1.13 & 1.09 & 9.10 & 8.53 & 8.82 & 3.54 & 3.35 & 3.45 \\
\hline SEd & 0.052 & 0.031 & & 0.386 & 0.403 & & 0.314 & 0.232 & \\
\hline CD 5\% & 0.118 & 0.070 & & 0.873 & 0.912 & & 0.710 & 0.524 & \\
\hline
\end{tabular}

\section{Effect of borax on seed yield and oil content}

Significant differences were observed between the treatments for seed husk ratio (Figure 4), seed yield and oil content (Table 2). Pollination with $75 \%$ pollen and $25 \%$ borax gave next highest yield (12.99 g) to control (14.84 g) (Figure 5). The reason may be that borax plays a major role in membrane integrity and cell wall development and it helps in pollen tube growth. The treatment $50 \%$ pollen and $50 \%$ 
borax filler materials also recorded significantly higher yield though pollen availability was reduced to 50\%. Increased seed yield due to borax application was reported by Patil et al. (1983) and Sutaria and Golakiya (1990) in groundnut. The effect on oil yield was also increased by increasing the percentage of pollen (Figure $6)$.

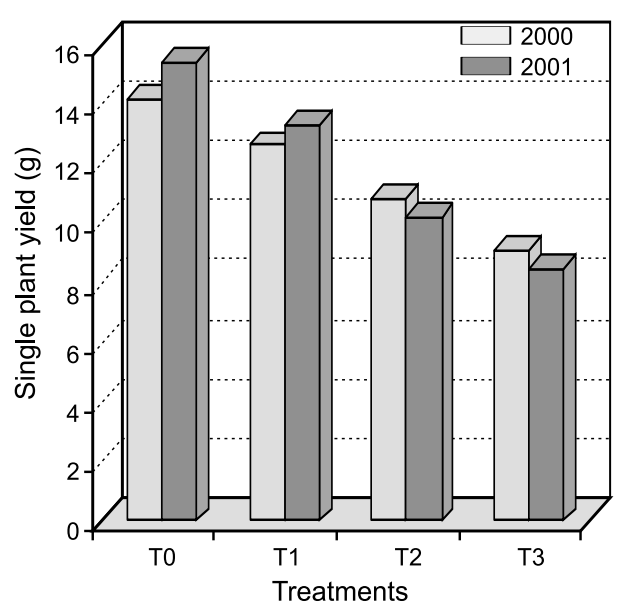

Figure 5: Effect of pollen and other filler materials on mean of plant yield in sunflower

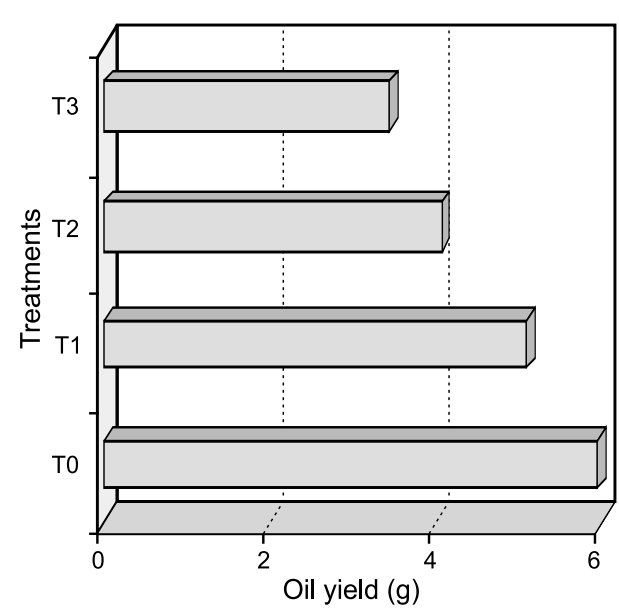

Figure 6: Effect of pollen and Borax on overall mean of oil yield in sunflower

Fifty percent of pollen with $50 \%$ of finger millet flour recorded the lowest yield. The finger millet flour is an inert matter and it doesn't have any chemical/biological effect on the pollen may be the reason for the lower yield.

Mean comparisons of the pollen treatments are: $\mathrm{T}_{0}>\mathrm{T}_{1}>\mathrm{T}_{2}>\mathrm{T}_{3}$

\section{Effect of pollen and borax on seed quality characters}

The seed quality characters, seedling length, germination percentage and seed vigor index, were affected by the mixtures of pollen and filler materials. All these three treatments were significantly different from each other (Table 3).

Table 3: Effect of pollen and borax on quality traits of sunflower

\begin{tabular}{|c|c|c|c|c|c|c|c|c|c|}
\hline \multirow{2}{*}{ Treatment } & \multicolumn{2}{|c|}{ Seedling length } & \multirow{2}{*}{ Mean } & \multicolumn{2}{|c|}{$\begin{array}{l}\text { Germination } \\
\text { percentage }\end{array}$} & \multirow{2}{*}{ Mean } & \multicolumn{2}{|c|}{ Seed vigor index } & \multirow{2}{*}{ Mean } \\
\hline & 2000 & 2001 & & 2000 & 2001 & & 2000 & 2001 & \\
\hline $\mathrm{T}_{0}$ & 29.62 & 31.25 & 30.44 & 95.15 & 96.95 & 96.05 & 2819.05 & 3029.3 & 2924.18 \\
\hline $\mathrm{T}_{1}$ & 26.07 & 28.88 & 27.48 & 91.28 & 93.53 & 92.41 & 2378.90 & 2700.3 & 2539.6 \\
\hline $\mathrm{T}_{2}$ & 23.68 & 24.08 & 23.88 & 86.90 & 87.53 & 87.22 & 2057.83 & 2107.5 & 2082.67 \\
\hline $\mathrm{T}_{3}$ & 19.43 & 19.38 & 19.41 & 83.70 & 82.50 & 83.10 & 1626.08 & 1598.8 & 1612.44 \\
\hline SEd & 0.545 & 0.643 & & 0.691 & 0.681 & & 48.44 & 50.84 & \\
\hline CD 5\% & 1.23 & 1.46 & & 1.56 & 1.54 & & 109.58 & 115.0 & \\
\hline
\end{tabular}

The effect of decreased percentage of pollen and increased percentage of filler materials was reflected clearly on these quality traits (Figures 7,8 ). The control per- 
formed well with $100 \%$ pollen, followed by $75 \%$ of pollen and $25 \%$ percent of borax. High vigor index was recorded with $100 \%$ pollen (Figure 9); since pollination was practically complete, the higher seed setting was reflected on seed yield.

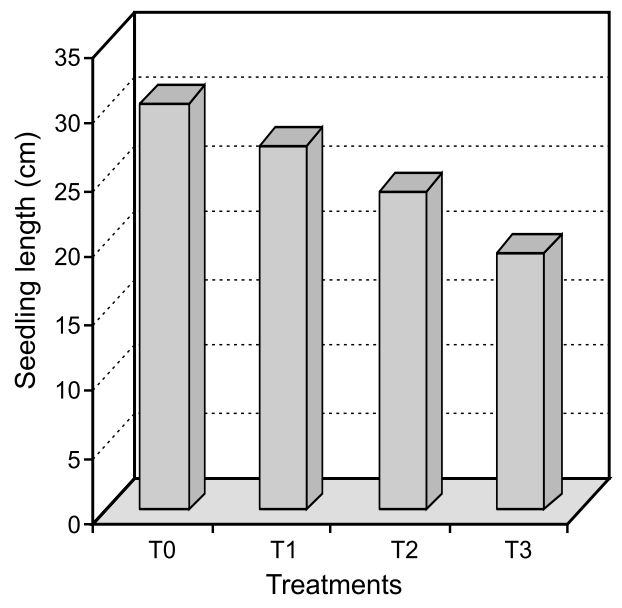

Figure 7: Relationship between percent of pollen on over all mean of seedling length in sunflower

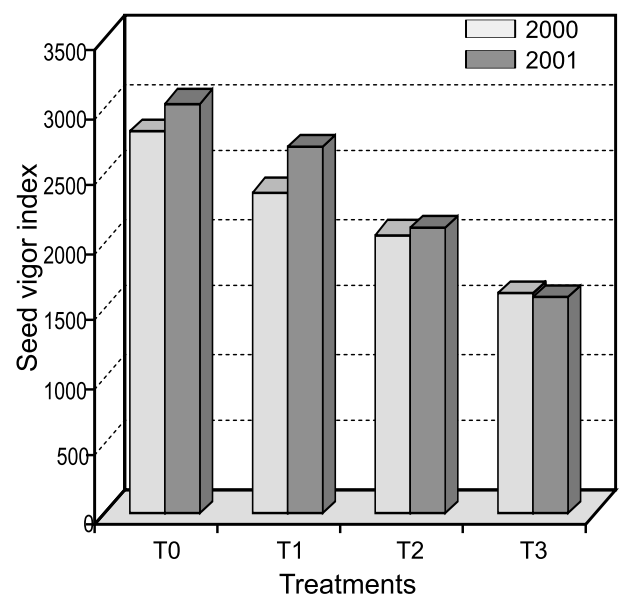

Figure 9: Relationship between percent of pollen on mean of seed vigor index in sunflower

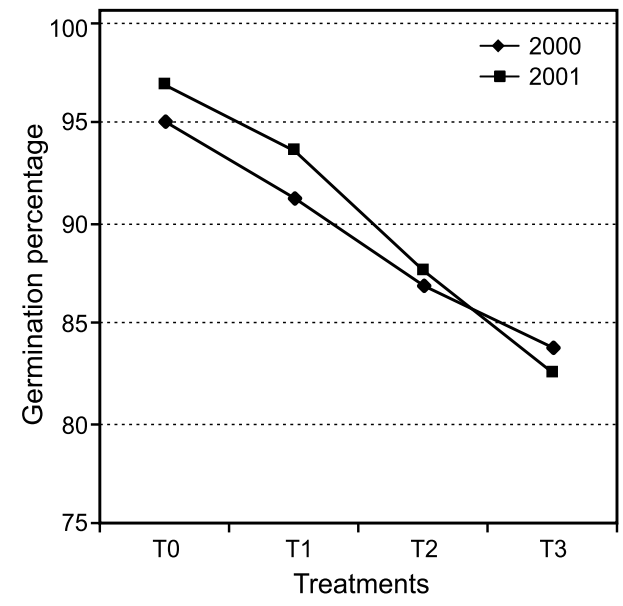

Figure 8: Effect of pollen and Borax on mean of percent germination in sunflower

These quality traits were much affected by the treatment with $50 \%$ pollen and $50 \%$ finger millet flour because the latter did not have any biological effect on pollination.

\section{CONCLUSION}

Although further investigations are needed to ascertain present result, a definite conclusion may be drawn from these findings. This study clearly indicates that the treatments were significantly different from each other. All the traits studied 
recorded superior performance only at $100 \%$ pollen availability; the seed yield increased only with an assured availability of sufficient pollen for fertilization. The mean comparisons of the treatments for all the characters was $T_{0}>T_{1}>T_{2}>T_{3}$. Though the seed yield was not increased to that much extent while supplementing with filler material, it is concluded that instead of $100 \%$ pollen $75 \%$ pollen with borax as filler material may be used without affecting the economic yield much in the case of pollen scarcity/pollen insufficiency/ pollen theft. Borax can be used as a supplement at the time of pollination. Use of filler material helps in uniform spreading of pollen on the stigma and economic use of pollen grains in case of pollen theft, especially in tropical/subtropical countries like India where bee activity is brisk from early morning and before pollination.

Apart from this, in hybrid seed production fields 25 percent of seed parent population can be increased to get more hybrid seed yield by increasing the ovule and pollen parent ratios from 3:1 to 4:1 in the case of KBSH-1 hybrid. The use of finger millet flour as the filler material during the pollination in the case of pollen insufficiency doesn't have any effect on the seed yield and yield attributing characters. In that case the yield was reflected, only for the $50 \%$ of pollen availability.

Regarding oil content the filler material borax does not have any effect on oil content. Instead, it affects oil yield by increasing the seed filling percentage and seed number per head.

\section{ACKNOWLEDGEMENT}

The authors are grateful to National Seed Project (Crops), ICAR, for providing necessary funds for conducting this experiment.

\section{REFERENCES}

Andrei, E., 1998. Determination of the pollen amount in pollen fertility restorer sunflower inbred lines. Cercetari Agronomice in maldova, Romania, 31: (3/4) 111- 120.

Habura, E.C.H., 1957. Parasterilitat bei sonnenblum. Z. Pflanzenzuecht 37: 280-298.

Narkhede, P.L. and Patil, A.J., 1989. Response of sunflower to foliar application of nutrients under drought condition. Indian Agric. Chem. 22: 197-200.

Panse, V.G. and Sukhatme, P.V., 1967. Statistical Methods for Agricultural Workers. I.C.A.R. New Delhi, 280-293.

Patil, J.D., Shinde, P.H., Shingte, A.K., Patil, N.D., 1983. Effect of boron application on groundnut yields. J. Maharashtra Agric. Univ. 8: 49-51.

Renukadevi, A., Savithri, P. and Andi, K., 2003. Sources, levels and methods of boron application on the dry matter production, yield attributes and yield of sunflower (Helianthus annuus L.) crop. Crop Research 25(3): 436-440.

Shankar Goud, I., Giriraj, K. and Vijayakumar, S., 2000. Studies on immediate effect of foreign pollen (Xenia) on resulting $\mathrm{F}_{0}$ seed characteristics in sunflower (Helianthus annuus L.). Helia 23(32): 59-64

Sindagi, S.S., 1979. Poor seed set in sunflower and means to alleviate it. Oilseeds J. 10: 28-32.

Sutaria, G.S. and Golakiya, B.A., 1990. Mechanism of yield control in groundnut by boron. Advance Pl. Sci. 3: 53-60. 
EFICIENCIA DE UTILIZACIÓN DE LAS LÍNEAS DE POLEN cms 234 A Y RHA 6D-1 DE GIRASOL (Helianthus annuus L.)

\section{RESUMEN}

El experimento de campo fue realizado en la estación de investigaciones en Bhavanisagar, Universidad de Agronomía Tamil Nadu, Coimbatore, La India, durante la temporada rabi (Sept.-Oct.) de 2000 y 2001, para estudiar la eficacia de utilización de polen de las líneas de girasol cms 234 A y RHA 6D-1. Los experimentos incluían cuatro tratamientos, $100 \%$ polen $\left(\mathrm{T}_{0}\right), 75 \%$ polen plus $25 \%$ bórax como medio complementario $\left(\mathrm{T}_{1}\right), 50 \%$ polen plus $50 \%$ bórax $\left(\mathrm{T}_{2}\right)$ y $50 \%$ polen y $50 \%$ de la harina de mojo (Eleusine coracana $\mathrm{L}$.) $\left(\mathrm{T}_{3}\right)$. Los resultados mostraron que los tratamientos diferían significativamente. Todas las características estudiadas confirmaron la superioridad del tratamiento con $100 \%$ de polen; el rendimiento de la semilla era significativamente incrementado cuando para la polinización era accesible la cantidad suficiente de polen. Los valores medios de los tratamientos de todas las características establecieron la relación $\mathrm{T}_{0}>\mathrm{T}_{1}>\mathrm{T}_{2}>\mathrm{T}_{3}$. Aunque el rendimiento de la semilla era disminuido en cierta medida por utilización del medio complementario, fue deducido que $75 \%$ de polen y $25 \%$ de bórax podían sustituir $100 \%$ de polen en los casos de carencia de polen en las localidades en las cuales "el robo de polen" está habitual. Bórax puede utilizarse como sustitución en la época de polinización. La utilización de la harina de mojo como cargador del material durante la polinización en el caso de carencia de polen, no tenía ninguna influencia en el rendimiento de semilla y otras características de rendimiento. En tal caso, solamente la cantidad de $50 \%$ de polen accesible, tuvo influencia en el rendimiento.

\section{EFFICACITÉ DE L'UTILISATION DU POLLEN DES LIGNÉES cms 234 A ET RHA 6D-1 DU TOURNESOL (Helianthus annuus L.)}

\section{RÉSUMÉ}

Une expérience sur le terrain a été effectuée à la Station de Recherche, Bhavanisagar, Tamil Nadu Agricultural University, Coimbatore, Inde durant les saisons de rabi (septembre-octobre) des années 2000 et 2001 dans le but d'analyser l'efficacité de l'utilisation de pollen des lignées de tournesol cms 234 A et RHA 6D-1. Les expériences consistaient en quatre traitements, $100 \%$ de pollen $\left(\mathrm{T}_{0}\right), 75 \%$ de pollen plus $25 \%$ de borax comme matériel complémentaire $\left(\mathrm{T}_{1}\right)$ et $50 \%$ pollen avec $50 \%$ de borax $\left(\mathrm{T}_{2}\right)$ et $50 \%$ de pollen et $50 \%$ de farine de millet (Eleusine coracana $\mathrm{L}$.) $\left(\mathrm{T}_{3}\right)$. Les résultats ont démontré que les traitements différaient significativement les uns des autres. Toutes les caractéristiques étudiées ont confirmé la supériorité du traitement avec $100 \%$ de pollen; le rendement en graines était significativement augmenté quand une quantité suffisante de pollen était accessible pour la fécondation. La valeur moyenne des traitements était de $\mathrm{T}_{0}>\mathrm{T}_{1}>\mathrm{T}_{2}>\mathrm{T}_{3}$ pour toutes les caractéristiques. Bien que le rendement en graines ait diminué dans une certaine mesure par l'ajout de matériel complémentaire, il a été conclu que $75 \%$ de pollen et $25 \%$ de borax pouvaient remplacer $100 \%$ de pollen dans les cas de manque de pollen dans les localités où le «vol de pollen » est fréquent. Le borax peut être utilisé comme remplacement lors de la pollinisation. L'utilisation de la farine de millet comme matériel complémentaire au cours de la pollinisation dans le cas de manque de pollen n'avait eu aucun effet sur le rendement de graines ni sur d'autres caractéristiques du rendement. Dans ce cas, seule la quantité de $50 \%$ de pollen accessible avait eu un effet. 